\title{
Factors Affecting the Immunization Approaches of Caregivers: An Example of a Teaching and Research Hospital
}

\author{
Ebeveynlerin Aşı Yaklaşımlarını Etkileyen Faktörler:
Bir Eğitim Araştırma Hastanesine Ilişkin Değerlendirme
}

\author{
Özlem Üzüm', Kayı Eliaçık', Hacer Hortu Örsdemir'', Eda Karadağ Öncel² \\ ${ }^{1}$ Clinic of Pediatrics, Health Sciences University, Tepecik Training and Research Hospital, Izmir, Turkey \\ ${ }^{2}$ Clinic of Pediatric Infectious Dieases, Health Sciences University, Tepecik Training and Research Hospital, Izmir, Turkey
}

\begin{abstract}
Cite this article as: Üzüm Ö, Eliaçık K, Hortu Örsdemir H, Karadağ Öncel E. Factors affecting the immunization approaches of caregivers: an example of a teaching and research hospital. J Pediatr Inf 2019;13(3):e114-e120.
\end{abstract}

\section{Abstract}

Objective: Immunization programs prevent diseases that could result in fatal or permanent disabilities in the field of health. Although technical facilities and healthcare personnel are the most important criteria in vaccination programs, the adaptation of caregivers to vaccination programs has increasingly become an important issue. In our study, it was aimed to determine the factors affecting the vaccination approaches of the caregivers and the level of knowledge regarding vaccine names.

Material and Methods: In this cross-sectional descriptive study, parents who applied to the pediatric outpatient clinic of our hospital for any reason during a six-month period were evaluated for their knowledge on and attitudes towards vaccines. In the questionnaire, demographic characteristics of families, income and education levels, number of children and presence of vaccination record cards of the children were sought with the face-to-face interview technique. In the survey, the names of routine vaccines made by the Ministry of Health of the Republic of Turkey and vaccines recommended in childhood were presented mixed, and they were asked to indicate the vaccines they knew.

Results: In the study, 302 questionnaires were included. Of the parents who participated, 268 were mothers. Majority of the cases $(254,84.1 \%)$ were found to have a vaccination record card. Having an only child was found to have a positive impact on the presence of a vaccination record card, regular immunization, knowledge on vaccines and immunization with the vaccines recommended in childhood. $84.1 \%$ (254) of the parents found vaccination necessary. Parents were most aware of measles
Öz

Giriş: Çocuk aşılama programları sonucunda sağlık alanında ölümcül veya kalıcı sakatlıklar ile sonuçlanabilecek birçok hastalıklara karşı korunma sağlanmaktadır. Aşılama programlarında teknik altyapı ve personel en önemli kriter olsa da bakım verenlerin aşı programlarına uyumu önemi artan bir durum haline gelmiştir.Çalışmamızda ebeveynlerin aşı yaklaşımlarını etkileyen faktörleri belirlemek ve aşı isimlerini bilme düzeylerini saptamak amaçlanmıştır.

Gereç ve Yöntemler: Bu kesitsel-tanımlayıcı çalışmada hastanemiz çocuk sağlığı ve hastalıkları polikliniğine altı aylık dönemde herhangi bir nedenle başvuran ebeveynlerin aşılar hakkındaki bilgi ve tutumları değerlendirildi. Ankette ebeveynlerle yüz yüze görüşme tekniği ile ailelerin demografik özellikleri, gelir ve eğitim düzeyleri, çocuk sayıları, çocukların aşı kartı varlığı sorgulandı. Ankette T.C. Sağlık Bakanlığı tarafından yapılan ve çocukluk çağında önerilen rutin olmayan aşıların isimleri karışık olarak sunuldu, bildikleri aşıları belirtmeleri istendi.

Bulgular: Araştırmaya 302 anket dahil edildi. Katılımcı olan ebeveynlerin 268 'i anneydi. Olguların çoğunluğunun $(254 ; \% 84.1)$ aşı kartı olduğu görüldü. Tek çocuk olmanın aşı kartı varlığını, aşıların düzenli yapılmasını, rutin olmayan aşıyı bilme ve yaptırmayı olumlu yönde etkilediği görüldü. Ebeveynlerin \%84.1 ( $n=254$ )'inin aşılamayı gerekli bulduğu saptandı. Ebeveynlerin en çok kızamık aşısından haberdar olduğu, hiçbir aşı ismini bilmeyen 91 (\%30.1) ebeveyn olduğu görüldü. Ebeveynlerin \%35.8'inin rutin

Yazışma Adresi / Correspondence Address

Özlem Üzüm

Sağlık Bilimleri Üniversitesi,

İzmir Tepecik Eğitim ve Araştırma Hastanesi,

Çocuk Sağlığı ve Hastalıkları Kliniği,

İzmir-Türkiye

E-mail: baspinarozlemm@hotmail.com 
vaccination, and there were 91 (30.1\%) parents who did not know any vaccination names. It was found that $35.8 \%$ of the parents heard of special vaccines not routinely performed, but only $15.6 \%$ of them were found to have been vaccinated with these vaccines not routinely performed. It was observed that as the level of education of the mother increased, the rate of being aware of vaccines and gettingthem increased.

Conclusion: In our study, it was concluded that having many children and the income and educationlevel of the caregiverseffect immunization. It was seen that caregivers prefer health centers for information on immunization and vaccines, and therefore it is important to give more information regarding immunization in health institutions. It is concluded that the adaptation of caregivers to extended immunization programs can be achieved by increasing their knowledge about vaccines and vaccine preventable diseases.

Keywords: Vaccine, child, caregivers, education

\section{Introduction}

Primary aim of healthcare services and personnel is to opportune people to lead healthy lives. Immunization is the most effective method providing protection from infectious diseases (1). Distinctive reduction in mortality and morbidity from many infections preventable with vaccines since the onset of childhood immunization programs started to be enforced as a state policy in the twentieth century $(2,3)$.

Although technical facilities and healthcarepersonnel are the most important criteria in vaccination programs, the adaptation of caregivers to vaccination programs has increasingly become an important issue $(2,4)$. In 2010 , it was seen that 19.3 million children were not fully vaccinated worlwide, and the rate of un-vaccinated children in some countries even reached up to $28 \%$ (5). Low education and income levels, sex, misinformation and lack of it have negatively affected immunization in studies conducted on the rates of vaccination (58). Nonetheless, vaccine hesitancy and rejection rates among socio-economically wealthy families in developed countries have risen tremendously in recent years (9-11). The concept of vaccine hesitancy that started in the 1990s in the world has gained popularity in our country since the year 2010. According to the statement by the Ministry of Health in December 2017, the number of families hesitant to vaccination surpassed 10.000 (12).

It has been seen that parental fear and worries towards vaccines are caused to a great extent by sharing misinformation and the declarations of anti-vaccination communities on social media (13-15). Relieving the anxiety towards vaccination is a must for the prevention of preventable diseases. Therefore, factors affecting vaccine implementation should be reviewed, and evaluation of caregivers's knowledge on vaccines and guiding the caregivers in the right manner are necessary (15). olmayan aşıları duyduğu, ancak \%15.6'sının rutin olmayan aşı yaptırdığı tespit edildi. Anne eğitim düzeyi arttıkça aşılardan haberdar olma ve yaptırma oranlarının arttığı görüldü.

Sonuç: Çalışmamızda ekonomik ve eğitim düzeylerinin, çok çocuk sahibi olmanın aşılama üzerindeki etkileri görülmüş, ebeveynlerin aşı bilgilerini sağlık merkezlerinden öğrenmeyi tercih ettikleri, bu sebeple sağlık kuruluşlarında bağışıklama hakkında daha geniş bilgi verilmesinin önemli olduğu sonucuna ulaşılmıştır. Ebeveynlerin genişletilmiş bağışıklama programlarına uyumunun, aşılar ve hastalıklar hakkında bilgilerinin arttırılması ile sağlanabileceği sonucuna ulaşılmıştır.

Anahtar Kelimeler: Aşı, çocuk, ebeveyn, eğitim

In light of this information, the aim of this study is to determine the factors affecting vaccine approaches of the caregivers and detect their level of knowledge regarding vaccine names.

\section{Materials and Methods}

In this cross-sectional descriptive study, caregivers who applied to the pediatric outpatient clinic of our hospital for any reason during a six-month period were evaluated for their knowledge on and attitudes towards vaccines. The study was commenced following the approcal of the local ethics committee (04.04.2018, decision No: 2018/3-14). Oral and written informed consent was taken form volunteering caregivers. The questionnaire was carried out by face-to-face intervies technique. Demographics of the families, their education and income levels and numbers of children were recorded. The child's age brought to the clinic for examnination was noted. The children were divided into two groups as those under and over the age of two since there is intense vaccination carried out in the first two years of life in the extended vaccination program of the Ministry of Health.

Presence of a vaccination record card, vaccination nececssity and side effects of vaccinations were questioned. The caregivers were asked if they had knowledge on cvaccines recommended in childhood but not covered by the Ministry of Helath. The names of the vaccines routinely carried out by the Ministry of Health of the Republic of Turkey (hepatitis B, BCG, DaTB-IPA-Hib, KPA, MMR, OPA, hepatitis A, varicella) and the names of the ones recommended in childhood but not routinely performed (influenza, rotavirus, human papilloma viris, and etc) were given mixed and the caregivers were asked to mark the ones they know about.

Chi-square test, numbers and percentages were used in the analysis of categorical (qualitative) variables. Binary comparisons in numeric data were performed on Students-t test and ternary comparisons were conducted with one-way ANO- 
VA test. Analyses of the current data were carried out on IBM SPSS 24 program (Statistical Package for Social Sciences, Chicago, IL, USA). $\mathrm{p}<0.05$ was accepted as statistical significance in all tests.

\section{Results}

314 patients, who applied to the pediatric outpatient clinic of our hospital, agreed to fill out the questionnaire. However, 12 questionnaires were excluded form the study since tehre were voids and contradictions in the responses of the caregivers, and 302 questionaires were included. $88.7 \%$ of the participant caregivers were mothers 9268), 7.6\% were fathers $(n=23)$ and $3.2 \%$ $(n=11)$ were other family members. $41.7 \%(n=126)$ of the children at time of application to the clinic was aged two and under, $58.3 \%(n=176)$ was aged two and over. Majority of the caregivers were in the age range of 30-39. The families were mainlyseen to have low-income and low education levels (Table 1).

Most of the cases, and especially those under the age of 2, were found to have vaccination record cards ( $n=254,84.1 \%$ ). It was established that failies with a single child statistically more regularly had the vaccinations done when compared to the families with three or more children. Presence of vaccination record card was found to be statistically higher in families with one child or two whne compared to those with three or more children (Table 2). It was determined that $84.1 \%$ of the caregivers $(n=254)$ found vaccination necessary, $5.6 \%(n=17)$ found it unnecessary and $10.3 \%(n=31)$ was indecisive. Despite these rates, only $1.4 \%(n=4)$ of the caregivers were seen to have not got their children vaccinated regularly with reasons other than diseases (Table 2). It was noticed that two of the parents that did not have their children vaccinated considered vaccination unnecessary and the other two were found indecisive. It was put forth that $81.5 \%$ of the caregivers learned about vaccines from healthcare centers, $9.9 \%$ from TV/radio/newspaper/internet, $4.4 \%$ from relatives/friends and another $4.4 \%$ did not find doing research on the subject relevant.

It was seen that half of the caregivers ( $n=162,53.6 \%$ ) believed that vaccines had side effects. As side effects, $62.9 \%$ ( $n=$ 102) of the caregivers indicated fever, $10.5 \%(n=17)$ emphasized rash and allergy, 9.2\% $(n=15)$ stated diarrhea, nausea and vomiting, $4.3 \%(n=7)$ expressed paralysis and $1.2 \%(n=2)$ pointed out seizures.

When the caregivers's knowledge on the names of the vaccines were evaluated, it was seen that they were mostly informed (54.8\%) about the measles vaccination. There were 91 patients (\%30.1) that did not know any vaccine names. It was found that $29.1 \%(n=78)$ of the mothers and $43.4 \%(n=10)$ of the fathers did not know the names of the vaccines of the Ministry of Health. Since there were only 23 fatheres participating
Table 1. Demographics of the caregivers

\begin{tabular}{|c|c|}
\hline & n (\%) \\
\hline \multicolumn{2}{|l|}{ Mother's age } \\
\hline$<20$ years & $7(2.3)$ \\
\hline 20-29 years & $103(34.1)$ \\
\hline 30-39 years & $130(43.0)$ \\
\hline$>40$ years & $62(20.5)$ \\
\hline \multicolumn{2}{|l|}{ Father's age } \\
\hline$<20$ years & $2(0.7)$ \\
\hline 20-29 years & $59(19.5)$ \\
\hline $30-39$ years & $136(45.0)$ \\
\hline$>40$ years & $104(34.4)$ \\
\hline \multicolumn{2}{|l|}{ Number of children } \\
\hline 1 & $121(40.1)$ \\
\hline 2 & $87(28.8)$ \\
\hline$\geq 3$ & $94(31.1)$ \\
\hline \multicolumn{2}{|l|}{ Mother's occupation } \\
\hline Housewife & $236(78.1)$ \\
\hline Worker & $31(10.3)$ \\
\hline Civil servant & $14(4.6)$ \\
\hline Other & $21(7.0)$ \\
\hline \multicolumn{2}{|l|}{ Father's occupation } \\
\hline Unemplyed & $21(7.0)$ \\
\hline Worker & $152(50.3)$ \\
\hline Civil servant & $20(6.6)$ \\
\hline Other & $108(35.8)$ \\
\hline \multicolumn{2}{|l|}{ Mother's education status } \\
\hline None & $25(8.3)$ \\
\hline Primary school $1^{\text {st }}$ stage & $113(37.4)$ \\
\hline Primary school $2^{\text {nd }}$ stage & $72(23.9)$ \\
\hline High school & $68(22.5)$ \\
\hline University & $24(7.9)$ \\
\hline \multicolumn{2}{|l|}{ Father's education status } \\
\hline None & $11(3.6)$ \\
\hline Primary school $1^{\text {st }}$ stage & $109(36.1)$ \\
\hline Primary school $2^{\text {nd }}$ stage & $74(24.5)$ \\
\hline High school & $75(24.7)$ \\
\hline University & $33(10.9)$ \\
\hline \multicolumn{2}{|c|}{ Family total income (YTL/month) } \\
\hline $0-1000$ & $63(20.9)$ \\
\hline $1001-2000$ & $119(39.4)$ \\
\hline $2001-3000$ & $72(23.8)$ \\
\hline$>3001$ & $48(15.9)$ \\
\hline
\end{tabular}


Table 2. Presence of vaccination record card and regular vaccination

\begin{tabular}{|c|c|c|c|}
\hline & \multicolumn{2}{|c|}{ n (\%) } & \\
\hline \multicolumn{4}{|c|}{ Were the vaccines regularly applied? } \\
\hline Yes & \multicolumn{2}{|c|}{$284(94.0)$} & \\
\hline No & \multicolumn{2}{|c|}{$18(6.0)$} & \\
\hline Was ill, postponed & \multicolumn{2}{|c|}{$12(4.0)$} & \\
\hline Do not find it necessary & \multicolumn{2}{|c|}{$2(0.7)$} & \\
\hline \multirow[t]{2}{*}{ Find it harmful } & \multicolumn{2}{|c|}{$2(0.7)$} & \\
\hline & \multicolumn{2}{|c|}{ Were the vaccines regularly applied? (\%) } & $p$ \\
\hline Patient age & Yes & No & $0.310^{*}$ \\
\hline$\leq 2$ years & $117(91.4)$ & $9(8.6)$ & \\
\hline$>2$ years & $167(94.8)$ & $9(5.2)$ & \\
\hline \multicolumn{4}{|l|}{ Number of children } \\
\hline 1 & $117(96.6)$ & $4(3.4)$ & $0.065^{* *}$ \\
\hline 2 & $83(95.4)$ & $4(4.6)$ & \\
\hline \multirow[t]{2}{*}{$\geq 3$} & $84(89.3)$ & $10(10.7)$ & \\
\hline & \multicolumn{2}{|c|}{ Presence of vaccination record card (\%) } & \\
\hline Patient age & Yes & No & \\
\hline$\leq 2$ years & $116(92.0)$ & $10(8.0)$ & $0.001 *$ \\
\hline$>2$ years & $138(78.4)$ & $38(21.6)$ & \\
\hline \multicolumn{4}{|l|}{ Number of children } \\
\hline 1 & 108 (89.2) & $13(10.8)$ & $0.008^{* *}$ \\
\hline 2 & $76(87.3)$ & $11(12.7)$ & \\
\hline$\geq 3$ & $70(74.4)$ & $24(25.6)$ & \\
\hline
\end{tabular}

Table 3. Mother's education status and knowledge on vaccine names

\begin{tabular}{|c|c|c|}
\hline & \multicolumn{2}{|c|}{$\begin{array}{c}\text { Knowledge on vaccines covered by } \\
\text { Ministry of Health (\%) }\end{array}$} \\
\hline & Yes* & No \\
\hline Mother's education status & & $11(52.4)$ \\
\hline None & $10(47.6)$ & $35(36.1)$ \\
\hline Primary school $1^{\text {st }}$ stage & $62(63.9)$ & $18(26.9)$ \\
\hline Primary school $2^{\text {nd }}$ stage & $49(73.1)$ & $12(20.0)$ \\
\hline High school & $48(80.0)$ & $2(8.7)$ \\
\hline University & $21(91.3)$ & No \\
\hline & Knowledge on non-routine vaccines \\
\hline & Yes* & $18(85.8)$ \\
\hline Mother's education status & $3(14.2)$ & $78(80.4)$ \\
\hline None & $19(19.6)$ & $48(71.7)$ \\
\hline Primary school $1^{\text {st }}$ stage & $19(28.3)$ & $37(61.7)$ \\
\hline Primary school $2^{\text {nd }}$ stage & $23(38.3)$ & $4(17.4)$ \\
\hline High school & $19(82.6)$ & \\
\hline University & \multicolumn{2}{|l}{} \\
\hline${ }^{*}$ Yes: means the mother knows one or more vaccine names.
\end{tabular}

in the questionnaire that the effect of father's education level was not evaluated. When that of the mothers was evaluated, $70.9 \%$ of the caregivers knew one or more names of the vaccines of the Ministry of Health, and as the level of education increased so did the level of knowledge on vaccines (Table 3 ).
It was determined that $35.8 \%$ of the caregivers heard about the vaccines not routinely performed but only $15.6 \%$ of them had these vaccines administered. It was seen that $70.5 \%$ ( $n=$ 213) pf the caregivers did not know which non-routine vaccine is protective against which diseases. $69 \%(n=185)$ of the mothers and $86.9 \%(n=20)$ of the fathers were found to have no knowledge on non-routine vaccines. When mothers were evaluated, it was noticed that $31 \%(n=83)$ was aware and informed of one or more non-routine vaccine and as the education level increased so did the level of being informed of non-routine vaccines (Table 3). Out of the non-routine vaccines, 19 children were vaccinated for rotavirus, four for meningococcus, and two for vacicella. As the income level of the family increased so did implementation of non-routine vaccines. With the increase in the number of children in the family, there found to be a reduction in the knowledge and implementation of non-routine vaccines (Table 4). Mothers were found to be more informed about rotavirus (16.4\%) and fathers about influenza (13\%) vaccines among all non-routine vaccines.

\section{Discussion}

Our study data revealed that low income and education level and having many children negatively affects vaccine awareness. Moreover, it was established that even though there is a group of caregivers with negative opinion on vacci- 
Üzüm et al.

Table 4. Evaluation of the caregivers approach to non-routine vaccinations and knowledge of their names

\begin{tabular}{|c|c|c|c|}
\hline & \multicolumn{2}{|c|}{$\begin{array}{c}\text { Knowledge on non-routine } \\
\text { vaccines (\%) }\end{array}$} & \multirow[b]{2}{*}{$p$} \\
\hline & Yes & No & \\
\hline \multicolumn{4}{|l|}{$\begin{array}{l}\text { Family total income } \\
\text { (YTL/month) }\end{array}$} \\
\hline $0-1000$ & $12(19.0)$ & $51(81.0)$ & \\
\hline $1001-2000$ & $38(31.9)$ & $81(68.1)$ & \\
\hline $2001-3000$ & 35 (48.6) & $37(51.4)$ & \\
\hline$>3001$ & $23(47.9)$ & $25(52.1)$ & \\
\hline Number of children & & & $<0.05^{*}$ \\
\hline 1 & $57(47.1)$ & $64(52.9)$ & \\
\hline 2 & $32(36.7)$ & $55(63.3)$ & \\
\hline \multirow[t]{3}{*}{$\geq 3$} & $19(20.2)$ & $84(79.8)$ & \\
\hline & \multicolumn{2}{|c|}{$\begin{array}{c}\text { Non-routine vaccination } \\
\text { practice (\%) }\end{array}$} & \\
\hline & Yes & No & \\
\hline \multicolumn{4}{|l|}{$\begin{array}{l}\text { Family total income } \\
\text { (YTL/month) }\end{array}$} \\
\hline $0-1000$ & $3(4.8)$ & $60(95.2)$ & \\
\hline $1001-2000$ & $17(14.2)$ & $102(85.8)$ & \\
\hline $2001-3000$ & $18(25.0)$ & $54(75.0)$ & \\
\hline$>3001$ & $9(18.8)$ & $39(81.2)$ & \\
\hline Number of children & & & $0.041 *$ \\
\hline 1 & $25(20.6)$ & $96(79.4)$ & \\
\hline 2 & $12(13.8)$ & 75 (86.2) & \\
\hline$\geq 3$ & $10(10.6)$ & $(89.4)$ & \\
\hline
\end{tabular}

nation, these caregivers complied with the National Immunization Program of the Ministry of Health.

Majority of the mothers applying to outpatient clinics in our study comprised of housewives. In field studies conducted in our country, the female population has been found to be notsatisfactorily involved in business life and has been determined as being housewives at a rate of $92 \%(4,16)$. Although outpatient clinic applications of the children were mostly made by mothers, the fact that one fourth of the mothers were employed and 24 caregivers were fathers made us consider that fathers also needed to be informed about vaccines. Although it has been observed that majority of the families has two children in field studies carried out in various cities of our country, one third of the applications to our hospital consisted families with three or more children. Education level of the mothers were mostly detected at the first stage and at similar rates with field studies $(2,4)$.

Regular practice of vaccines in our study was found to be high $(76.4 \%)$ as regards Turkish Population and Health Research (TPHR, 2013) data. Similar to TPHR data,percentage of regular vaccination under the age of two was detected to be higher. Even though the increase in the number of children cause setbacks in vaccination, vaccination percentage was found higher in all groups with regard to TPHR-2013 data (16).

It has been emphasized in field studies carried out in Turkey that the most important source of knowledge on immunization in the healthcare workers $(4,15,17)$. International studies have insisted on the fact that caregivers search about vaccines on the internet and the negative data on these resources has led to an increase in vaccine hesitancy and rejection (3). Moreover, it is seen that caregivers rely on information found in physician group websites the most $(9,18)$. Again participants having a relative or a friend who lives abroad and has gone through a negative experience on vaccines stated vaccine hesitancy or higher rates of rejecting doctor's recommendations $(19,20)$. In a field study taken place in 2016 regarding vaccine necessity, $98.1 \%$ of the caregivers agreed but the number of caregivers unwilling to have their children vaccinated increased from 183 in 2011 to 980 in 2013, 5400 in 2015 and 12.000 in 2016, and case number regarding vaccine hesitancy has increased up to 23.000 by the year 2018 $(4,21)$. It was seen in our study that caregivers continued to get their children vaccinated despite negative opinions on the matter. These results made us consider that their answers regarding vaccine necessity were contradictory and this condition was due to not being sufficiently informed on the matter. Fever was the answer given by most caregivers regrading the question on side effects. Side effects like infertility, autism and reduction in immunity stated in field studies were not put forward $(15,17,22)$, which made us believe that caregivers reached sufficient and accurate information on vaccines in healthcare institutions where they most frequently received information regarding vaccines and immunization.

When factors affetcting vaccination status in the studies conducted, Uzuner et al. have found that mother's education and income level, social security and having tetanus vaccination in this process are effective; Aktürk et al. have concluded that mother's education level and monthly income, Ayçiçek et al. have established that mother's education level, place of settlement (countryside or city), socioeceonomic environement and family's economic status are effective. On the other hand, Altun et al. have stated that education and income levels of the caregivers do not have any impact on vaccination $(2,4,23-25)$. Furthermore, field studies put forth that the rate of the number of children in the family and what number the children brought to the outpatient clinic is affect getting vaccinated and knowledge level of vacciens $(15,26,27)$. In a study conducted in the province Diyarbakır, the increase in the birth rank of the child decreases vaccination rate and having many children negatively affects vaccination (28). A study carried out in the UK has similarly detected that the increase in sibling numbers is related to the delay in vaccination (26). However, a study centered in Kayseri has demonstrated that full vacci- 
nation rates of three or more siblings are higher than those of two or eless siblings (29). In our study, as the level of income and education level of the caregivers increased so did the knowledge on routine and non-routine vaccine names. Moreover, the increase in the number of siblings led to a decrease in the presence of a vaccination record card, regular practice of vaccinations and knowledge on the names of non-routine vaccines and having them.

In field studies questioning the caregivers's level of knowledge regarding non-routine vaccines on Turkey, it has been found that two thirds of the caregivers do not know any non-routine vaccines and the ones who do could count influenza, measles and meningitis vaccines at the first place $(2,4)$. Particulary bringing forward chronic patients or elderly patients who are not vaccinated due to influenza in the media causes the perception that this vaccine is not necessary in the pediatric age group. Therefore, the importance of pediatric influenza vaccination should be better conveyed and positive attitudes of the public and healthcare workers should be supported (30). It was seen in our study that caregivers knew about measles vaccination among the vaccines implemented by the Ministry of Health the most. The changes in the measles vaccination policy that have occurred in the last five years have increased sensitivity of the caregivers.

Since only caregivers applying to the outpatient clinic of our hospital during a selected period of time and accepting to participate in the study were included into our study, the results reflect a cross-sectional period and our number is limited. Due to its location, caregivers applying to our hospital come from low income and low educational backgrounds, and thus, healthier results will be reached if these factors are put forth in a more heterogenous study population. When vaccine hesitancy is considered to be higher in certain regions where the education levels of caregivers is high, low vaccine hesitancy detected in our study might be related to this fact (9).

The effects of low income and education levels and having many children on vaccination were seen in our study and we drew the conclusion that caregivers did not possess sufficient knowledge on the matter. It was seen that caregivers preferred healthcare centers to get the information they need on vaccines, and it was concluded that providing caregivers with extensive knowledge on immunization in healthcare centers and having healthcare workers share the correct information on the internet with the caregivers were important. It should be kept in mind that compliance to extended immunization programs can be provided with increase in knowledge on diseases and vaccines and that caregivers are a part of the immunization program.
Ethics Committe Approval: Local ethics committee approval was received (04.04.2018, decision no: 2018/3-14).

Peer-review: Externally peer-reviewed.

Author Contributions: Concept - ÖÜ; Design - ÖÜ, KE; Supervision ÖÜ, EKÖ; Materials - ÖÜ; Data Collection and/or Processing - ÖÜ, HHÖ; Analysis and/or Interpretation - All of authors; Literature Review - ÖÜ; Writing - All of authors; Critical Review - All of authors.

Conflict of Interest: No conflict of interest was declared by the authors.

Financial Disclosure: The authors declared that this study has received no financial support.

\section{References}

1. Hacettepe Üniversitesi. Halk Sağlığı Kavramı (Erişim Tarihi: 06.02.2019, http://www.halksagligi.hacettepe.edu.tr/hakkinda/kavram.php).

2. Altun ş. 6-14 yaş arası çocuklarda aşılanma oranı ve ailelerin özel aşılarla ilgili bilgi düzeyi. Uzmanlık Tezi. İstanbul, 2008.

3. Danova J, Salek J, Kocourkova A, Celko AM. Factors associated with parental refusal of routine vaccination in the Czech Republic. Cent Eur J Public Health 2015;23:321-3.

4. Incili HD. Çocuk polikliniklerimize başvuran çocukların annelerinin aşılar ile ilgili bilgi düzeyi. Uzmanlık Tezi. İstanbul, 2009.

5. Bosch-Capblanch X, Banerjee K, Burton A. Unvaccinated children in years of increasing coverage: how many and who are they? Evidence from 96 low- and middle-income countries. Tropical Medicine \& International Health 2012;17:697-710.

6. Lewin S, Hill S, Abdullahi LH, de Castro Freire SB, Bosch-Capblanch X, Glenton $C$, et al. 'Communicate to vaccinate' (COMMVAC) building evidence for improving communication about childhood vaccinations in low- and middle-income countries: protocol for a programme of research. Implement Sci 2011;6:125.

7. Merten S, Hilber AM, Biaggi C, Secula F, Bosch-Capblanch X, Namgyal $P$, et al. Gender determinants of vaccination status in children: evidence from a meta-ethnographic systematic review. PLoS One 2015;10:e0135222.

8. Taiwo L, Idris S, Abubakar A, Nguku P, Nsubuga P, Gidado S, et al. Factors affecting access to information on routine immunization among mothers of under 5 children in Kaduna State Nigeria, 2015. Pan Afr Med J 2017;27:186.

9. Wagner AL, Boulton ML, Sun X, Huang Z, Harmsen IA, Ren J, et al. Parents' concerns about vaccine scheduling in Shanghai, China. Vaccine 2017;35:4362-7.

10. Dempsey AF, Schaffer S, Singer D, Butchart A, Davis M, Freed GL. Alternative vaccination schedule preferences among parents of young children. Pediatrics 2011;128:848-56.

11. Luthy KE, Beckstrand RL, Peterson NE. Parental hesitation as a factor in delayed childhood immunization. J Pediatr Heal Care 2009;23:388-93.

12. Bozkurt HB. Aşı reddine genel bir bakış ve literatürün gözden geçirilmesi. Kafkas J Med Sci 2018;8:71-6.

13. Tustin JL, Crowcroft NS, Gesink D, Johnson I, Keelan J, Lachapelle B. Facebook recruitment of vaccine-hesitant Canadian parents: cross-sectional study. JMIR Public Health Surveil 2017;3:e47. 
Üzüm et al.

14. Larson HJ, Jarrett $C$, Eckersberger E, Smith DM, Paterson P. Understanding vaccine hesitancy around vaccines and vaccination from a global perspective: a systematic review of published literature, 2007-2012. Vaccine 2014;32:2150-9.

15. Argüt N, Yetim A, Gökçay G. Aşı kabulünü etkileyen faktörler. Çocuk Dergisi 2016;16:16-24.

16. Hacettepe Üniversitesi Nüfus Etütleri Enstitüsü Ankara, Türkiye Nüfus ve Sağlık Araştırması-2013 (Erişim Tarihi: 06.02.2019, http://www.hips. hacettepe.edu.tr/tnsa2013/rapor/TNSA_2013_ana_rapor.pdf).

17. Gellin BG, Maibach EW, Marcuse EK, for the National Network for Immunization Information Steering Committee. Do parents understand immunizations? A national telephone survey. Pediatrics 2000;106:1097-102.

18. Tafuri S, Gallone MS, Cappelli MG, Martinelli D, Prato R, Germinario C. Addressing the anti-vaccination movement and the role of HCWs. Vaccine 2014;32:4860-5.

19. Wheelock A, Parand A, Rigole B, Thomson A, Miraldo M, Vincent C, et al. Socio-psychological factors driving adult vaccination: a qualitative study. PLoS One 2014;9:e113503.

20. Savage EJ, Nash S, McGuinness A, Crowcroft NS. Audit of tetanus prevention knowledge and practices in accident and emergency departments in England. Emerg Med J 2007;24:417-21.

21. T.C. Sağlık Bakanlığı Sağlık Bilgi Sistemleri Genel Müdürlüğü. Sağlık Istatistikleri Yıllığı 2017 Haber Bülteni, 2018.

22. Özkan Ö, Çatıker A. Bolu il merkezindeki çocukların aşılılık durumları ve engelleri. Sürekli Tıp Eğitimi Dergisi 2006;15:171-8.
23. Aktürk Y, Ceyhun AG, Ekiner AS, Kurtay G. Gebe kadınların ve yeni doğum yapmıs annelerin çocukluk çağı aşıları hakkındaki bilgi düzeyi. VI. Ulusal Aile Hekimliği Kongresi Kongre Kitabı. Bursa, 2004:107.

24. Özmert Elif N. Dünyada ve Türkiye'de aşılama takvimindeki gelişmeler. Çocuk Sağlığı ve Hastalıkları Dergisi 2008;51:168-75.

25. Ayçiçek A. Şanlıurfa kırsal alanında 2-23 aylık çocukların aşılanma hızları. Çocuk Sağlığı ve Hastalıkları Dergisi 2004;47:183-8.

26. Reading $R$, Surridge $H$, Adamson $R$. Infant immunization and family size. J Public Health 2004;26:369-71.

27. Gust DA, Strine TW, Maurice E, Smith P, Yusuf H, Wilkinson M, et al. Underimmunization among children: effects of vaccine safety concerns on immunization status. Pediatrics 2004;114:e16-e22.

28. Yiğitalp G, Ertem M. Diyarbakır ilinde 0-12 aylık çocukların aşıya devamsızlık nedenleri. TAF Preventive Medicine Bulletin 2008;7:277-84.

29. Gülgün $M$, Fidancı $K$, Karaoğlu A, Güneş Ö, Kesik $V$, Altun $S$, et al. Bir askeri hastanenin çocuk polikliniğine başvuran çocukların 0-24 ay arasındaki aşılama durumlarının değerlendirilmesi. Gülhane Tıp Dergisi 2014;56:13-6.

30. Cairns G, MacDonald L, Angus K, Walker L, Cairns-Haylor T, et al. Systematic literature review of the evidence for effective national immunisation schedule promotional communications. ECDC 2012; http://hdl. handle.net/1893/10782. 